Original Article

\title{
Analysis of the genetic diversity of Dragon fruit based on ISSR markers in Colombia
}

\author{
Análise da diversidade genética da fruta do dragão com base em marcadores ISSR na \\ Colômbia
}

\author{
A. C. Morillo $\mathrm{a}^{*}$ (D), M. S. Morab (1) and Y. Morilloc (D) \\ aUniversidad Pedagógica y Tecnológica de Colombia, Facultad de Ciencias Agropecuarias, Tunja, Boyacá, Colombia \\ bUniversidad Pedagógica y Tecnológica de Colombia, Grupo Competitividad Innovación y Desarrollo Empresarial - CIDE, Tunja, Boyacá, \\ Colombia \\ ‘Corporación Colombiana de Investigación Agropecuaria - AGROSAVIA, Palmira, Valle del Cauca, Colombia
}

\begin{abstract}
Selenicereus megalanthus $\mathrm{H}$. is a tropical fruit belonging to the family Cactaceae, is rich in essential nutrients, antioxidants and bioactive components. It presents wide variability in different characteristics and a great demand in the market; however, genetic studies in Colombia are scarce. The main of this study was to characterize the genetic diversity of 76 yellow pitahaya genotypes with eight ISSR markers. Genetic parameters expected average heterozygosity (He), percentage of polymorphic loci, genetic distances and Fst were estimated with TFPGA. The analysis of the population genetic structure was carried out with the STRUCTURE 2.3.4. As a result, 225 alleles were generated and the number of polymorphic loci ranged 85 (CT, AG) to 90 (GT). High genetic diversity was found, with an average value of heterozygosity was 0.34 with a genetic differentiation coefficient (Fst) of 0.26 , indicating that there was a great genetic diversity, similar values than those reported in other studies of pitahaya genetic diversity in Colombia. The 76 genotypes were grouped into $\mathrm{K}=3$ according to geographic location, however, in some groups a mixture of individuals from different origins was observed. The analysis of molecular variance (AMOVA) showed higher variation (75\%) within groups than among groups (25\%). These results provide information that can be used to develop conservation strategies for dragon fruit and breeding programs to obtain more productive pitahaya genotypes with superior quality, high yield and with resistance to biotic and abiotic factors.
\end{abstract}

Keywords: Selenicereus megalanthus, breeding, genetic markers, germplasm, genetic structure.

\section{Resumo}

Selenicereus megalanthus H. é uma fruta tropical pertencente à família Cactaceae, rica em nutrientes essenciais, antioxidantes e componentes bioativos. Apresenta grande variabilidade em diferentes características e uma grande demanda no mercado; no entanto, os estudos genéticos na Colômbia são escassos. O principal deste estudo foi caracterizar a diversidade genética de 76 genótipos de pitahaya amarela com oito marcadores ISSR. Parâmetros genéticos esperados de heterozigosidade média (He), porcentagem de locos polimórficos, distâncias genéticas e Fst foram estimados com TFPGA. A análise da estrutura genética da população foi realizada com a ESTRUTURA 2.3.4. Como resultado, 225 alelos foram gerados e o número de loci polimórficos variou de 85 (CT, AG) a 90 (GT). Foi encontrada alta diversidade genética, com um valor médio de heterozigosidade de 0,34 com coeficiente de diferenciação genética (Fst) de 0,26, indicando que havia uma grande diversidade genética, valores semelhantes aos relatados em outros estudos de diversidade genética de pitahaya na Colômbia. Os 76 genótipos foram agrupados em $\mathrm{K}=3$ de acordo com a localização geográfica, porém, em alguns grupos foi observada uma mistura de indivíduos de diferentes origens. A análise de variância molecular (AMOVA) mostrou maior variação (75\%) dentro dos grupos do que entre os grupos (25\%). Esses resultados fornecem informações que podem ser utilizadas para desenvolver estratégias de conservação da fruta do dragão e programas de melhoramento para a obtenção de genótipos de pitahaya mais produtivos, com qualidade superior, alto rendimento e com resistência a fatores bióticos e abióticos.

Palavras-chave: Selenicereus megalanthus, melhoramento, marcadores genéticos, germoplasma, estrutura genética.

\section{Introduction}

Pitaya or Pitahaya also known as Dragon fruit, belonging to the family Cactaceae, this fruit is mainly produced in tropical and subtropical countries with a dry climate and $18-28^{\circ} \mathrm{C}$ temperature; it has very specific characteristics such as its exuberant yellow thorny peel, and white pulp with many small and black seeds; its native to Andean region and geographically distributed in Bolivia, Peru, Ecuador, Venezuela, Mexico, Brazil, Costa Rica and

*e-mail: ana.morillo@uptc.edu.co

Received: September 16, 2021 - Accepted: December 16, 2021 
Colombia (González et al., 2019). It is considered an exotic cacti specie, with characteristic, eye-catching fruits. Their popularity is due to the unique appearance rich source in antioxidants (vitamins and minerals), as well as dietary fiber and low calories, flavonoids and phenolic acids, but especially betacyanins (Pásko et al., 2021), natural food pigments rarely found in edible products; with important biological properties (Zain et al., 2019), which may be helpful in prevent some oxidative stress-related disorders (Quiroz et al., 2018), prevent cancer, diabetes, cardiovascular, respiratory, gastrointestinal and urinary diseases (Thokchom et al., 2019). For this reason, it has drawn worldwide attention, not only to its new flavour, color and attractive appearance but also their enormous health benefits (Abirami et al., 2021; Pásko et al., 2021).

It gained great commercial potential in worldwide by consumer preference for new exotic phyto-chemically rich nutrient fruits and its adaptability to new environment with abiotic stress tolerance like drought and temperature extremes. Pitahaya mayor importers are the United States, Japan, European Union and Canada, while major exporters are: Israel, Mexico and Nicaragua, in addition, Colombia participate with $38 \%$ of the international exportations (Agronet, 2021).Selenicereus production reaching $17773 \mathrm{t}$ during 2018, the principal production departments include Huila, Santander and Boyacá (Agronet, 2021). Boyacá is one of the richest departments in natural resources, with energy, road and adequate infrastructure and a privileged geographical position allowed to have focused their economic activity in traditional agriculture, it is 12 producing municipalities of pitahaya to know: Berbeo, Briceño, Buenavista, Chitaraque, Coper, Miraflores, Otanche, Páez, San Eduardo, Santana, Tunungua and Zetaquira, which have the productive potential to make pitahaya an economically profitable crop. It has remained stable yield for dragon fruit, by 2018, it had a planted area of 397 ha, with a yield $6.59 \mathrm{t} \mathrm{ha}^{-1}$, although its production decreased from 2017 to 2018 with 2,615 to 2,420 tons, respectively (Agronet, 2021).

Despite the productive potential, a limiting factor in the development of this crop in Colombia is the incidence of pest and diseases, low quality of the fruit, the technological level, the associativity and the lack of cultivated material which generating significant losses in yield, (Morillo et al., 2016; González et al., 2019).

Different research institutions and universities have tried to find a solution to these problems (Martínez et al., 2015). These studies show that there is no certified planting material and that only a few are grown by farmers, which generates vulnerability to different phytosanitary problems, for which it is necessary to carry out genetic studies that lead to the identification of elite materials that meet the needs of the productive chain of yellow dragon fruit in Colombia, since the genetic base of germplasm resources is limited. The characterization of the genetic diversity of the populations and the identification of the pitahaya species was done previously based on morphological characteristics (Mejía et al., 2013); however, these are strongly influenced by the environment, therefore molecular identification has become the main tool for characterization and management of germplasm collections of many species fruit trees (Dotor et al., 2016).

The application of this type of biotechnological tools has made it possible to identify the genetic relationships between the genera Hylocereus and Selenicereus, evaluate the fertility of triploid and aneuploid hybrids between Hylocereus polyrhizus and Selenicereus megalanthus, and demonstrate the allopolyploid origin of these species (Oliveira et al., 2020). To date, several DNA markers have been used to evaluated the genetic diversity of pitahaya, including random-amplified polymorphic DNA (RAPD) (Rifat et al., 2019), amplified fragment length polymorphism (AFLP) (Pagliaccia et al., 2015), simple sequence repeats (Nashima et al., 2021), and inter simple sequence repeats (ISSRs) (Zhijiang et al., 2021).

Among the microsatellite markers, the ISSRs are characterized by their simple handling, low cost, high polymorphism and high stability (Abirami et al., 2021); they are very useful to measure genetic diversity in plants and animals and identify relationships between families, species and within species also is a feasible approach for small laboratories, requires no prior genetic information. Work on genetic diversity in fruit species suggests that the technique is useful for identifying duplicate materials or accessions within germplasm collections and establishing relationships between species (Martínez et al., 2020).

In Colombia there are few studies of genetic diversity in yellow dragon fruit, especially in the department of Boyacá, only the research carried out by Morillo et al. (2017) who carried out the molecular characterization of 12 yellow dragon fruit materials in the province of Lengupá using seven ISSRs markers, finding that there is genetic variability that can be exploited for the identification of elite materials. In this context, the objective of this study was characterize of yellow dragon fruit genotypes from different municipalities in the department of Boyacá using ISSR molecular markers, generating fundamental information to understand the genetic background for the orientation of conservation strategies and use of genetic resources.

\section{Material and Methods}

\subsection{Material vegetal}

The yellow pitahaya genotypes ( $S$. megalanthus) were collected from the producing municipalities in the department of Boyacá: Berbeo, Zetaquira, Paéz, San Eduardo and Miraflores, from farms where the vegetative seeds were selected (Table 1 ).

\subsection{Molecular characterization}

The molecular characterization was carried out in the Laboratorio de Investigaciones en Biología Molecular Vegetal at the Universidad Pedagógica y Tecnológica de Colombia, in Tunja at $2.820 \mathrm{msnm}$, with an average temperature of $13^{\circ} \mathrm{C}$.

The DNA extraction were done with the protocol of Dellaporta et al. (1983). The total DNA was visualized with 
Table 1. Geographical georeferencing of collected sites genotypes pitahaya (S. megalanthus) evaluated.

\begin{tabular}{|c|c|c|c|c|c|}
\hline \multirow{2}{*}{ ID Farmer } & \multirow{2}{*}{ ID Genotypes } & \multicolumn{2}{|c|}{ Georeferencing } & \multirow{2}{*}{ Village } & \multirow{2}{*}{ Municipality } \\
\hline & & Latitude $\mathbf{N}$ & Longitude W & & \\
\hline \multirow[t]{4}{*}{1} & 1 & N 05 14' 121" & W $073^{\circ} 11^{\prime} 949^{\prime \prime}$ & Rusa & Miraflores \\
\hline & 2 & & & & \\
\hline & 3 & & & & \\
\hline & 4 & & & & \\
\hline \multirow[t]{4}{*}{2} & 5 & N $05^{\circ} 14^{\prime} 003^{\prime \prime}$ & W $073^{\circ} 12^{\prime} 233^{\prime \prime}$ & Rusa & \\
\hline & 6 & & & & \\
\hline & 7 & & & & \\
\hline & 8 & & & & \\
\hline \multirow[t]{4}{*}{3} & 9 & $\mathrm{~N} 05^{\circ} 13^{\prime} 43,800$ & W $073^{\circ} 12^{\prime} 11,8^{\prime \prime}$ & Rusa & \\
\hline & 10 & & & & \\
\hline & 11 & & & & \\
\hline & 12 & & & & \\
\hline \multirow[t]{4}{*}{4} & 13 & N $05^{\circ} 13^{\prime} 37,9^{\prime \prime}$ & W $073^{\circ} 12^{\prime} 22,3^{\prime \prime}$ & Rusa & \\
\hline & 14 & & & & \\
\hline & 15 & & & & \\
\hline & 16 & & & & \\
\hline \multirow[t]{4}{*}{5} & 17 & N $05^{\circ} 12^{\prime} 850^{\prime \prime}$ & W 7309' 655" & Rusa & \\
\hline & 18 & & & & \\
\hline & 19 & & & & \\
\hline & 20 & & & & \\
\hline \multirow[t]{4}{*}{6} & 21 & N $05^{\circ} 12^{\prime} 850^{\prime \prime}$ & W $073^{\circ} 09^{\prime} 655^{\prime \prime}$ & Hato & \\
\hline & 22 & & & & \\
\hline & 23 & & & & \\
\hline & 24 & & & & \\
\hline \multirow[t]{6}{*}{7} & 25 & N $05^{\circ} 14^{\prime} 09,2^{\prime \prime}$ & W $073^{\circ} 12^{\prime} 15,3^{\prime \prime}$ & Rusa & \\
\hline & 26 & & & & \\
\hline & 27 & & & & \\
\hline & 28 & & & & \\
\hline & 53 & & & & \\
\hline & 54 & & & & \\
\hline \multirow[t]{4}{*}{8} & 29 & $\mathrm{~N} 05^{\circ} 13^{\prime} 46,5^{\prime \prime}$ & W $073^{\circ} 12^{\prime} 23,2^{\prime \prime}$ & Rusa - La Vega & \\
\hline & 30 & & & & \\
\hline & 31 & & & & \\
\hline & 32 & & & & \\
\hline \multirow[t]{4}{*}{9} & 33 & N 05 13'03,3" & W $073^{\circ} 09^{\prime} 42,8^{\prime \prime}$ & Pueblo y Cajón & \\
\hline & 34 & & & & \\
\hline & 35 & & & & \\
\hline & 36 & & & & \\
\hline
\end{tabular}


Table 1. Continued...

\begin{tabular}{|c|c|c|c|c|c|}
\hline \multirow{2}{*}{ ID Farmer } & \multirow{2}{*}{ ID Genotypes } & \multicolumn{2}{|c|}{ Georeferencing } & \multirow{2}{*}{ Village } & \multirow{2}{*}{ Municipality } \\
\hline & & Latitude N & Longitude W & & \\
\hline \multirow[t]{4}{*}{10} & 37 & N 05 17’3065" & W $073^{\circ} 10$ “153” & Centro - Rural & Zetaquira \\
\hline & 38 & & & & \\
\hline & 38 & & & & \\
\hline & 40 & & & & \\
\hline \multirow[t]{4}{*}{11} & 41 & N 05 15’ 129" & W $073^{\circ} 09^{\prime} 56,23^{\prime \prime}$ & Centro & \\
\hline & 42 & & & & \\
\hline & 43 & & & & \\
\hline & 44 & & & & \\
\hline \multirow[t]{4}{*}{12} & 45 & $\mathrm{~N} 05^{\circ} 14^{\prime} 33,41^{\prime \prime}$ & W $073^{\circ} 11^{\prime} 55,79^{\prime \prime}$ & Guanata - Portavelo & \\
\hline & 46 & & & & \\
\hline & 47 & & & & \\
\hline & 48 & & & & \\
\hline \multirow[t]{4}{*}{13} & 49 & N $05^{\circ} 14^{\prime} 24,2^{\prime \prime}$ & W $073^{\circ} 12^{\prime} 29,2^{\prime \prime}$ & Guanata & \\
\hline & 50 & & & & \\
\hline & 51 & & & & \\
\hline & 52 & & & & \\
\hline \multirow[t]{4}{*}{14} & 55 & N 05 13’ 45,5” & W $073^{\circ} 11^{\prime} 35,8^{\prime \prime}$ & Rusa & Miraflores \\
\hline & 56 & & & & \\
\hline & 57 & & & & \\
\hline & 58 & & & & \\
\hline \multirow[t]{4}{*}{15} & 59 & N $05^{\circ} 11^{\prime} 52,4^{\prime \prime}$ & W $073^{\circ} 11^{\prime} 17,3^{\prime \prime}$ & Suna Arriba & \\
\hline & 60 & & & & \\
\hline & 61 & & & & \\
\hline & 62 & & & & \\
\hline \multirow[t]{2}{*}{16} & 63 & N $05^{\circ} 12^{\prime} 16,3^{\prime \prime}$ & W $073^{\circ} 11^{\prime} 17,6^{\prime \prime}$ & Suna Arriba & \\
\hline & 64 & & & & \\
\hline \multirow[t]{2}{*}{17} & 65 & N $05^{\circ} 13^{\prime} 58,1^{\prime \prime}$ & W $073^{\circ} 09^{\prime} 55,3^{\prime \prime}$ & Suna Abajo & \\
\hline & 66 & & & & \\
\hline \multirow[t]{2}{*}{18} & 67 & N $05^{\circ} 07^{\prime} 57,5^{\prime \prime}$ & W $073^{\circ} 02^{\prime} 57,9^{\prime \prime}$ & Yamuntica & Páez \\
\hline & 68 & & & & \\
\hline \multirow[t]{2}{*}{19} & 69 & N $05^{\circ} 08^{\prime} 14,6^{\prime \prime}$ & W $073^{\circ} 03^{\prime} 12,0^{\prime \prime}$ & Yamuntica & \\
\hline & 70 & & & & \\
\hline \multirow[t]{2}{*}{20} & 71 & N $05^{\circ} 11^{\prime} 07,2^{\prime \prime}$ & W $073^{\circ} 06^{\prime} 08,3^{\prime \prime}$ & Batabajo & Berbeo \\
\hline & 72 & & & & \\
\hline \multirow[t]{2}{*}{21} & 73 & N $05^{\circ} 11^{\prime} 33,65^{\prime \prime}$ & W $073^{\circ} 03^{\prime} 40,04 "$ & Aguablanca & San Eduardo \\
\hline & 74 & & & & \\
\hline \multirow[t]{2}{*}{22} & 75 & N $05^{\circ} 13^{\prime} 02,0^{\prime \prime}$ & W $073^{\circ} 06^{\prime} 38,6^{\prime \prime}$ & Berbeo & Berbeo \\
\hline & 76 & & & & \\
\hline
\end{tabular}


0.8\% agarose gels in a Maxicell Primo EC-340 electrophoresis chamber. A Hoefer Dyna Quant 200 fluorometer were used to determine the concentration, with dilution using HPLC water for a total volume of $100 \mathrm{ul}$ at $10 \mathrm{ng} / \mathrm{ul}$, stored at $-20^{\circ} \mathrm{C}$. Eight ISSR markers that have been useful in determining genetic diversity in Selenicereus were used (Morillo et al., 2017) (Table 2).

For the amplification, the cocktail was prepared in a sterile microcentrifuge tube $(1.5 \mathrm{ml})$ for a final volume of $25 \mu$ l. Reaction components are indicated as final concentration. The reaction mixture was prepared with $1 \mathrm{X}$ buffer, 1.5 mM MgCl2, 0.2 mM dNTPs, 1 U Taq Polymerase, $2 \mu \mathrm{M}$ primer and $10 \mathrm{ng}$ genomic DNA. The amplification was carried out in

a programmable thermal controller thermal cycler (PTC-100, MJ Research, St. Bruno, Canada). The initial denaturation was $95^{\circ} \mathrm{C}$ for $5 \mathrm{~min}$; 37 cycles of denaturation at $95{ }^{\circ} \mathrm{C}$ for $30 \mathrm{~s}$, and hybridization: $58{ }^{\circ} \mathrm{C}(\mathrm{GT}, \mathrm{CGA}), 50{ }^{\circ} \mathrm{C}$ (AG, CA, ACA), and $55^{\circ} \mathrm{C}$ (CCA, TG, CT) for $45 \mathrm{~s}$, with an extension of $72{ }^{\circ} \mathrm{C}$ for $2 \mathrm{~min}$. The final extension was at $72{ }^{\circ} \mathrm{C}$ for $7 \mathrm{~min}$. We included a negative control or blank without DNA to confirm the absence of contamination. The amplicons were loaded onto $1.5 \%$ agarose gels run at $100 \mathrm{~V}$ for 2 h, stained with GelRed, and visualized on UV transilluminator M-15.

\subsection{Data analysis}

Amplified products were scored as present (1) or absent ( 0 ) to construct a binary matrix. For the selection of polymorphic loci were determined as ones in which the frequency of the most common allele was less than 95\%. Statistical analyses were performed using NTSYSPC (Numerical Taxonomy System for Personal Computers), version 2.02 PC, Setauket, New York, USA). TFPGA (Tool for Population Genetic Analysis) version 1.3 (Miller, Northern Arizona University, Flagstaff, Arizona, USA), STRUCTURE version 2.3.1 (Pritchard et al., 2000) and GenAlEx version 6.5 program (Peakal, Australian National University, Canberra, Australia).

Genetic similarity (GS) was estimated for all genotype pairs using the Equation 1 (Nei and Li, 1979):

$$
G S i j=2 N i j /(2 N i j+\cdot N i+\cdot N j)
$$

Table 2. ISSR markers used to determine the genetic diversity in the yellow dragon fruit.

\begin{tabular}{cc}
\hline Primer & Sequence $\left(\mathbf{5}^{\prime}\right.$ to $\mathbf{3}^{\prime}$ ) \\
\hline CCA & $\mathrm{DDB}(\mathrm{CCA})_{5}$ \\
CGA & $\mathrm{DHB}(\mathrm{CGA})_{5}$ \\
GT & $\operatorname{VHV}(\mathrm{GT})_{5} \mathrm{G}$ \\
AG & $\mathrm{HBH}(\mathrm{AG})_{7} \mathrm{~A}$ \\
CT & $\mathrm{DYD}(\mathrm{CT})_{7} \mathrm{C}$ \\
TG & $\mathrm{HVH}(\mathrm{TG})_{7} \mathrm{~T}$ \\
CA & $\mathrm{DBDA}(\mathrm{CA})_{7}$ \\
ACA & $\mathrm{BDB}(\mathrm{ACA})_{5}$ \\
\hline
\end{tabular}

The following designations are used for the generative sites: $\mathrm{H}$ (A or $\mathrm{T}$ or $\mathrm{C}) ; \mathrm{B}(\mathrm{G}$ or $\mathrm{T}$ or $\mathrm{C}) ; \mathrm{V}(\mathrm{G}$ or $\mathrm{A}$ or $\mathrm{C})$ and $\mathrm{D}(\mathrm{G}$ or $\mathrm{A}$ or $\mathrm{T})$. where GSij represents the similarity estimate between the genotypes $\mathrm{i}$ and $\mathrm{j}$, based on the ISSR data, $N i j$ is the total number of bands common to i and $\mathrm{j}$, and $\mathrm{Ni}$ and $\mathrm{Nj}$ correspond to the number of bands found in genotypes $\mathrm{i}$ and $\mathrm{j}$.

The matrix generated with the GS estimates was used to cluster the genotypes in a dendrogram obtained by the unweighted pair group with arithmetic mean (UPGMA) using NTSYS. Cophenetic correlation coefficient between similarity matrix and dendrogram cophenetic values was estimated to validate the dendrogram in relation to the original similarity estimates and the binary data matrix analyzed using COPH and MXCOMP programs in NTSYS-pc. The parameters of genetic diversity were estimated with TFPGA program, where the percentage of polymorphic loci and the heterozygosity were unbiased.

The unbiased statistical "F" value was determined with a $95 \%$ confidence interval. We performed a Bayesian analysis using STRUCTURE statistical package to determine the population structure of the genotypes using an admixture model, correlated allelic frequencies, and 10 iterations for each $\mathrm{K}$ (number of clusters assumed) with a burning of 100.000 interactions, followed by 200.000 Monte Carlo Markov Chains (MCMC). We selected the most probable number of clusters using delta $K(\Delta \mathrm{k})$ method using Structure Harvester (Evanno et al., 2005). Finally, the molecular variance analysis (AMOVA) was done with the GenAlEx 6.5.

\section{Results}

The genetic characterization of 76 yellow pitahaya or yellow dragon fruit genotypes using eight ISSR primers yielded a total of 225 bands with an average of 28.12 bands for each primer. The number of bands per primer varied from 24 for CT and CCA, to 36 for TG, with molecular weights between 140 to $1450 \mathrm{~kb}$ (Table 3). Among eight ISSR primers screened, all of them showed amplification and produced reproducible amplified bands.

Table 3. Number of loci, percentage of polymorphic loci, Fst and average expected heterozygosity (He) for the eight ISSRs evaluated in 70 Pitahaya genotypes.

\begin{tabular}{cccccc}
\hline Primer & $\mathbf{N}^{\circ}$ Loci & $\begin{array}{c}\text { Polymorphic } \\
\text { loci \% }\end{array}$ & Fst & He & $\begin{array}{c}\text { Standard } \\
\text { deviation }\end{array}$ \\
\hline TG & 36 & 86 & 0.25 & 0.30 & 0.05 \\
GT & 31 & 90 & 0.47 & 0.34 & 0.05 \\
AG & 30 & 90 & 0.33 & 0.37 & 0.04 \\
CA & 26 & 85 & 0.27 & 0.38 & 0.05 \\
CCA & 24 & 88 & 0.16 & 0.34 & 0.03 \\
ACA & 28 & 88 & 0.25 & 0.36 & 0.04 \\
CT & 24 & 96 & 0.17 & 0.36 & 0.05 \\
CGA & 26 & 88 & 0.16 & & 0.04 \\
Total & $\mathbf{2 2 5}$ & $\mathbf{8 9}$ & $\mathbf{0 . 2 6}$ & & $\mathbf{0 . 0 4}$ \\
\hline
\end{tabular}


The electrophoretic profile of ISSR markers study showed highly distinct and polymorphic banding pattern in primers CT, AG and GT. Range of polymorphic bands and \% polymorphism observed were $2-8$ and $85-90$, respectively.

The expected average heterozygosity were 0.29 to 0.38 for the CGA and CA primers, respectively (Table 3 ). The GT showed a greater genetic differentiation between the materials, with a genetic differentiation coefficient (Fst) of 0.47 , demonstrating that it is useful to differentiate among genotypes of Hylocereus and Selenicereus (Table 3).

For the total population, the percentage of polymorphic loci and the expected average heterozygosity $(\mathrm{He})$ were $89 \%$ and 0.34 , respectively (Table 3 ). The Fst obtained when screened pitahaya materials with the eight ISSR markers were 0.26 , with a standard deviation of 0.04 (Table 3 ). According to Wright (1978), values greater than 0.25 show great genetic differentiation.

The UPGMA analysis clustered the 76 genotypes into three groups (I, II, III) at a similarity level of 0.55 (Figure 1 ), where groups I and II have a similarity coefficient of 0.45 , while group III is at a distance of 0.25 with respect to the other two groups formed. It can be seen that material 21 is the one that shares the least characteristics with the three clades formed. The distinct groups were supported by a high cophenetic correlation coefficient ( $\mathrm{r}=0.96$ ).

Group I comprised 27 genotypes collected in the municipality of Miraflores, of which 24 correspond to the village of La Rusa and three to the Hato (Table 1). In this group, subgroups were formed according to characteristics such as high or low productivity observed in the field. Group II, with 28 genotypes, clusters the majority of genotypes of Miraflores (24) from different villages as Rusa, Pueblo y Cajón y Suna, and four genotypes from Zetaquira $(37,38,39,40)$. The clustering trend due to high and low productivity was also maintained. Lastly, group III at level of similarity of 0.25 , comprised genotypes collected from Zetaquira $(43,44,45,46,47,48,49,50,51$, 52) Berbeo $(71,72)$ San Eduardo $(73,74)$ y Paéz $(67,68,69$, 70 ). The material of pitahaya 21 were the least related to the other genotypes. Overall, our results demonstrate that ISSR markers can discriminate genotypes of Selenicereus according to their origin.

We analyzed the population structure of 75 genotypes of yellow pitahaya based on a Bayesinan model approached implemented using STRUCTURE v. 2.3.1. The Evanno method showed a $\Delta \mathrm{k}$ peak at $\mathrm{K}=3$, indicating that the genotypes are partitioned into three genetic groups, designated here as G1, G2, and G3 (Figure 2).

Seventy-five genotypes were assigned to the three groups; particularly, the majority of genotypes were assigned groups A y B with 27 and 28 individuals, respectively, while group III contained 20 genotypes. We assigned an individual to a given population based on a probability threshold of $70 \%$. In the Figure 2 the values for Delta K are observed, indicating the probability of the different $\mathrm{K}$ (genetic groups), where $\mathrm{K}=3$ being the most

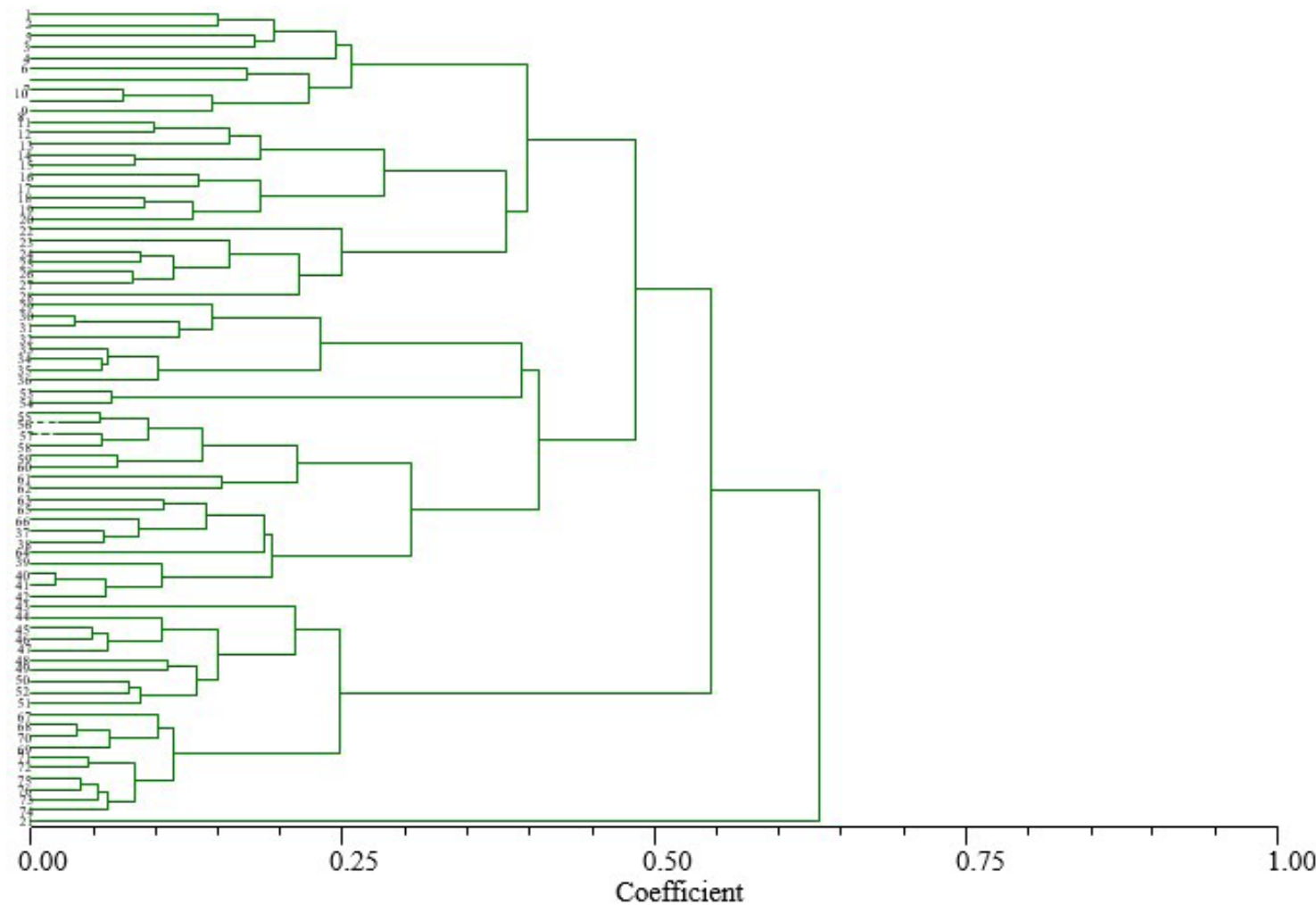

Figure 1. Dendrogram showing relationships among 70 genotypes of Selenicereus megalanthus, according to the UPGMA analysis using eight ISSR markers. 
probable number. Figure 3 show the structure analysis population genetics for $\mathrm{K}=3$; It is evidenced that the materials collected in Miraflores correspond to the first and second genetic groups and that the materials from the other municipalities correspond to the third genetic group, however, the interaction of some individuals in other genetic groups different from those of its geographical origin.

In the dendrogram, Figure 4, the relationship between groups I and II can be better observed and how they separate from group III, where there are individuals from different municipalities and villages of Zetaquira, San Eduardo, Paéz and Berbeo. The previous results are corroborated with the matrix of genetic distances of Nei and Li (1979), where the greatest distance is given by group three, which had already been observed in the dendrograms previously.

The analysis of molecular variance (AMOVA) showed that $75 \%$ of the variation was due to differences within groups, while $25 \%$ was attribute to differences among groups (Table 4 ).

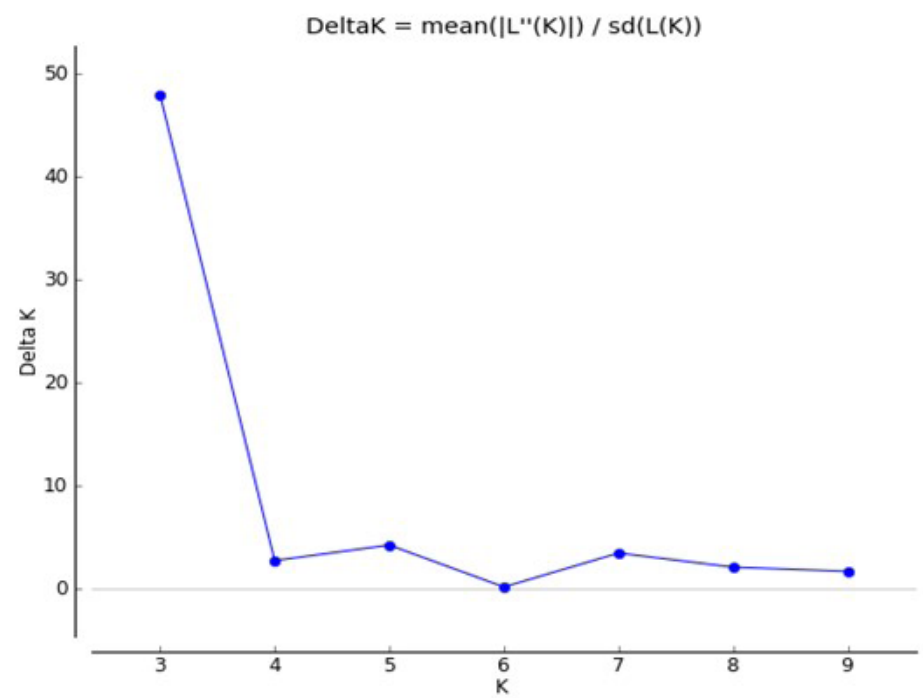

Figure 2. Delta K values obtained from Harvester Structure, calculated as the mean of the probability of K divided by the standard deviation of the probability of $\mathrm{K}$.
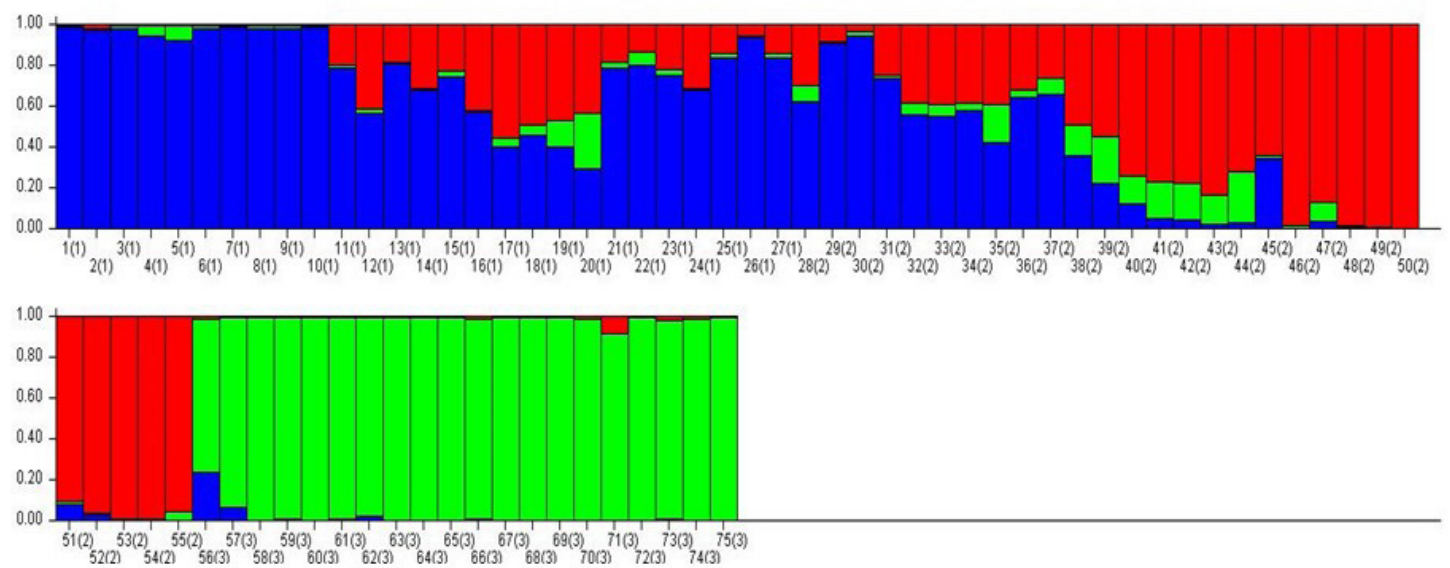

Figure 3. Population genetic structure of Pitahaya for each sample analyzed, estimated using the Structure software.

Table 4. Analysis of molecular variance (AMOVA) among and within populations using seven ISSR markers.

\begin{tabular}{lccccc}
\hline \multicolumn{1}{c}{ Source } & df & Sum of squares & $\begin{array}{c}\text { Variance } \\
\text { components }\end{array}$ & Total variation \% & p-value* $^{*}$ \\
\hline Among Pops & 2 & 652,573 & 11,745 & $25 \%$ & 0.001 \\
Within Pops & 72 & 2565,934 & 35,638 & $75 \%$ & 0.01 \\
Total & 74 & 3218,507 & 47,383 & $100 \%$ & \\
\hline
\end{tabular}

${ }^{*}$ Significance test after 1000 permutations. df: Degre of freedom. 

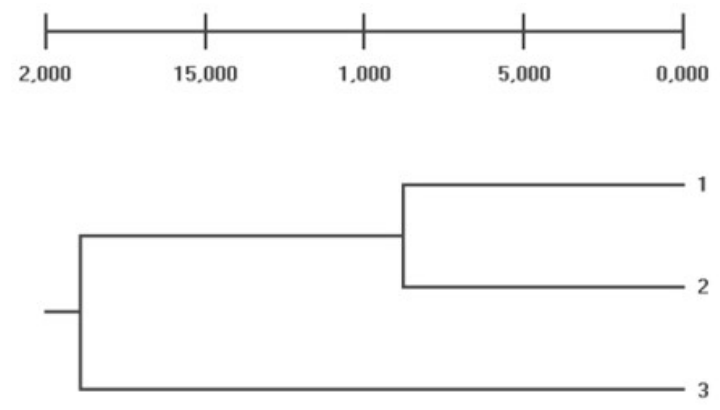

Figure 4. UPGMA dendrogram prepared from the genetic distances (Nei and Li, 1979) of the pitahaya populations.

\section{Discussion}

Yellow pitahaya (S. megalanthus) or dragon fruit is an exotic a promising tropical fruit, originating in Central America, it has a high nutritional value, highlighting content of ascorbic acid, and antioxidant capacity, superior to that of other cacti. It present and bioactive compounds, with health benefits (Thokchom et al., 2019; Pásko et al., 2021). In Colombia the crop of pitahaya mainly comes from the empirical process of farmers for this reason we can see morphological and genetic heterogeneity on fruit and others characters like vegetative structures, which leads to confusion to identify them at botanic, taxonomic or specie level (Morillo et al., 2016; Abirami et al., 2021). So, the present study was determined the genetic diversity in yellow pitahaya using molecular ISSR markers to determine the existing genetic variation in the producing municipalities of Colombia, as an approach towards the conservation and genetic improvement of the species.

In order to establish a strategy and management plant for phytogenetic resources for pitahaya, it is necessary to begin studies on morphological, agronomic, physiological and molecular characterizations, in this sense, eight ISSR evaluated in 76 genotypes of yellow pitahaya generated 225 bands, with $89 \%$ polymorphism. The number of bands and the percentages of polymorphism found in this study are suitable for estimating genetic parameters when compared with others research that used ISSR markers (Morillo et al., 2017; Abirami et al., 2021; Zhijiang et al., 2021). Taking into account the definition of Ott (1992), that consider marker like polymorphic, if $\mathrm{H}$ is greater than or equal to 0.1 and highly polymorphic if it is greater than or equal to 0.7 , so ISSR are polymorphic markers that for discrimination of closely related pitahaya individuals (Morillo et al., 2017; Abirami et al., 2021; Zhijiang et al., 2021).

The polymorphic bands and percentage polymorphism obtained in this study was almost comparable with results of Abirami et al. (2021) who evaluated sixteen ISSR primers, which generated 178 reproducible amplified bands. Range of polymorphic bands and \% polymorphism observed were 1-13 and 20-93, respectively. At an international level, other studies using different marker systems have also shown a high level of polymorphism in the germplasm of Selenicereus and Hylocereus (Rifat et al., 2019; Nashima et al., 2021). The GT marker made the greatest contribution to the observed variation with 0.48 Fst which means it can be useful for the differentiation of germplasm of genus
Selenicereus in intra-interspecific genetic diversity studies (Morillo et al., 2017).

The average estimated heterozygosity value and percentage of polymorphic loci for the total population was 0.34 and $89 \%$, respectively. The coefficient obtained in evaluation 76 genotypes with eight ISSR markers was 0.26 , show high genetic differentiation, which may be reflected in the high degree of domestication that these germplasms have suffered, since most of them are commercial materials (Morillo et al., 2017; Abirami et al., 2021). Zhijiang et al. (2021) evaluated 69 accessions of dragon fruit germplasm from Nannig, China with 13 ISSRs and detected a total of 247 loci, the percentage of polymorphic bands was $94 \%$ and the expected heterozygosity was 0.27 , a value lower than that found in this study. Studies of genetic diversity in other species of the Cactacea family have found heterozygosity values higher than those reported in this study, highlighting the high phenotypic and genetic variability of the germplasm of these species (García Aguilar et al., 2013). The results obtained above can also be explained by nature of markers, genome coverage and reproductive factors (Self-pollination, cross pollination, seed dispersal, ploidy level, exchange of plant material for sown between farmers and also gene flow between cultivated and wild species) which subject these species to their natural environment (Li et al., 2018).

García Aguilar et al. (2013), carried out a molecular characterization of three species of Hylocereus (Cactaceae) present in Mexico using the chloroplast regions matK, $r b c L$ and $p s b A$ and the intergenic spacer trnL-F as a barcode. The results found allowed the identification of different levels of intra and interspecific variation. In Colombia, Caetano et al. (2011), characterized the pitahaya germplasm bank of the National University of Colombia, Palmira campus using the ISSR technique, which allowed the discrimination of materials according to the genus that Selenicereus (S. megalanthus from Colombia and Selenicereus spp from Brazil) and Hylocereus. It also allowed the detection of possible duplicate accessions from the departments of Boyacá, Valle del Cauca and Risaralda. In the grouping analysis it was observed that $S$. megalanthus shows a lower coefficient of variation in relation to Hylocereus spp. The average heterozygosity for the total population was 0.14 , revealing little genetic polymorphism in the groups analyzed, which suggests a low variability among the yellow pitahaya accessions. These results may be associated with the autogamous nature of the plants and the type of preferential asexual reproduction in the multiplication of materials. The previous results are much lower than those found in this study and those made by Morillo et al. (2017) in the province of Lengupá $(\mathrm{He}=0.34$, polymorphic loci $=$ 82 ), which suggests that there is genetic variability in the study area, which can be used within the strategies that lead to the identification of elite materials adapted to the area with better production and good phytosanitary behavior.

The molecular variance analysis AMOVA showed that the genetic variation observed in the evaluated pitahaya genotypes was mainly within groups with $75 \%$ (Table 4). This high variation could show the presence of higher levels of subdivision and hierarchy. The remaining $25 \%$ was due to the component of genetic variance between groups, which was significant $(\mathrm{P} \leq 0.001)$; such genetic variation between 
groups might be used for conservation and breeding of this species. Similar results have been reported in other studies of genetic diversity in other fruit species using ISSR markers (Morillo et al., 2017; Castañeda-Cardona et al., 2020; Martínez et al., 2020).

Our cluster analysis demonstrate that ISSR markers can discriminate genotypes in three groups according to their geographic origin (Figure 2, Figure 3 and Figure 4). In addition, there is a laxa distribution of individuals within each of the groups and subgroups formed, typical of the spatial-temporal dynamics to which these genotypes are subjected within the productive systems. It is worth highlighting the tendency of materials with high and low productivity to be grouped together. Taking into account the similarity indices are high for groups I and II, where the largest number of individuals collected in the municipality of Miraflores are found, results similar to those obtained by Morillo et al. (2017), where higher similarity values were found and only two groups were formed according to the geographical origin of the evaluated materials. However, the results found in this study show genetic parameters with higher genetic diversity values and lower similarity indices, in relation to the research carried out by Caetano et al. (2011), in Valle del Cauca, Colombia.

These materials are being evaluated in a morphological characterization study, where these characters have shown a fairly homogeneous structure, however variable characters have been found in relation to the fruit, pulp and seed (unpublished data). Morphological characterization studies in yellow pitahaya materials from the departments of Boyacá, Huila, Valle del Cauda and Santander, show that there is a low variability which could not be separated by geographical sites since they maintain the same genetic diversity (Caetano et al., 2011).

Regarding the genetic similarity with the structure program, three groups $\mathrm{K}=3$ (Figure 2) were clearly generated, where the third group presented greater difference, with respect to the other two, possibly due to the fact that this group was made up of genotypes collected in different village of the municipalities of Zetaquira, San Eduardo, Páez and Berbeo; Mixed genotypes were also found in the different groups, which may be due to their similarity in terms of the common cultivation area, the reproductive biology of the species, the exchange of vegetative seed between farmers in the province of Lengupá and environmental factors and anthropic characteristics of the domestication process of these species (Caetano et al. 2011; Morillo et al., 2016).

The grouping found in this study shows that despite the morphological uniformity observed the similarity indexes so high, population structure can also be influenced for level of ploidy, reproductive way, it is an autogamous species, with preferentially asexual reproduction, there is variability which is reflected in that it does not There is a consistent formation of groups by geographical origin, but there is a laxa distribution of the materials through the evaluated sites and there is variability between the materials of the same path which can be used to obtain new cultivated materials. The results show the existence of genetic diversity in the evaluated yellow pitahaya materials, contrary to that reported in other studies of both molecular and morphological characterization in germplasm from Colombia (Caetano et al., 2011; Morillo et al., 2016).

The molecular analysis of variance (AMOVA) showed that the highest genetic variance was found between individuals, with a value of $75 \%$ (Table 4 ), and a low percentage of differences between populations, results similar to those reported by Caetano et al. (2011) and Morillo et al. (2017) in studies of genetic diversity in yellow pitahaya in Colombia. This suggests that the populations studied are not statistically variable, since there is little differentiation between the populations studied, this is possibly due to the fact that inbreeding is occurring and the same varieties are always cultivated.

Conventionally, morphological traits had been used to differentiate plant germplasm/ species and to elucidate their genetic relationship. Though there were distinct morphological differences exists in stem, flower and fruit characters in this genus Selenicereus, molecular characterization of them will help in elucidating the genetic relationship and diversity among the genotypes, likewise, the biochemical characterization in the search for bioactive components with industrial or medicinal use, are complementary studies that would successfully support a genetic improvement program in the search and identification of elite materials that meet the needs of the farmer, producer and consumer (Zain et al., 2019; Pásko et al., 2021).

Knowledge on inter- and intraspecific genetic diversity provides useful information for effective conservation, management of plant genetic resources and breeding programs (Abirami et al., 2021). Variability between genotypes is important for breeders in the selection of high-yield varieties, so the existence of variability among individuals is a prerequisite for the production of new varieties aimed at improving crop productivity, with the ability to resist the impacts of biotic or abiotic stress (Caetano et al., 2011; Morillo et al., 2017; González et al., 2019).

Colombia has the genetic and agro-ecological potential to increase the cultivation of yellow pitahaya, especially in the department of Boyacá, where there are more than five producing municipalities and producer associations. There is genetic variability that can be conserved and characterized in search of better planting materials, for which it is necessary to complement the molecular studies with the morphoagronomic and biochemical characterization that allows us to carry out a more efficient selection process for thus from the generation of new and better varieties, provide a solution to the main problems faced by this production system in the province of Lengupá and at the same time serve as a model for all other yellow pitahaya producing departments in Colombia and the world.

\section{Acknowledgements}

The authors gratefully acknowledge the: "Patrimonio Autónomo Fondo Nacional de Financiamiento para la Ciencia, la Tecnología y la Innovación Francisco José de Caldas- MinCiencias. Gobernación de Boyacá". Cód: 110986575466 , for the research financial support. 


\section{References}

ABIRAMI, K., SWAIN, S., BASKARAN, V., VENKATESAN, K., SAKTHIVEL, K. and BOMMAYASAMY, N., 2021. Distinguishing three Dragon fruit (Hylocereus spp.) species grown in Andaman and Nicobar Islands of India using morphological, biochemical and molecular traits. Scientific Reports, vol. 11, no. 1, pp. 2894. http://dx.doi. org/10.1038/s41598-021-81682-x. PMid:33536453.

CAETANO, M.C., TAMAYO, F., MUÑOZ, J.E., MORALES, J.G., SUÁREZ, R.S., SANDOVAL, C.L., MARTÍNEZ, M.A., CAÑAR, D.Y., PEÑA, R.D., SÁNCHEZ, E., GALÍNDEZ, E., ROJAS, R.D., JIMÉNEZ, J.R., BENAVIDES, A.E. and PÉREZ, L.F., 2011. Enfoque multidisciplinario para solución en el agro colombiano: el caso Pitahaya amarilla Selenicereus megalanthus. Revista de la Asociación Colombiana de Ciencias Biológicas, vol. 1, no. 23, pp. 52-64.

CASTAÑEDA-CARDONA, C.C., MORILLO-CORONADO, Y. and MORILLO, A., 2020. Assessing the genetic diversity of Dioscorea alata and related species from Colombia through inter-simple sequence repeat (ISSR) markers. Chilean Journal of Agricultural Research, vol. 80, no. 4, pp. 608-616. http://dx.doi.org/10.4067/S071858392020000400608 .

DELLAPORTA, S.L., WOOD, J. and HICKS, J.B., 1983. A plant DNA minipreparation: version II. Plant Molecular Biology Reporter, vol. 1, no. 1, pp. 19-21. http://dx.doi.org/10.1007/BF02712670.

DOTOR, M.Y., GONZÁLEZ, L.A., CASTRO, M.A., MORILLO, A.C. and MORILLO, Y., 2016. Análisis de la diversidad genética de la mora (Rubus spp.) en el departamento de Boyacá. Biotecnologia en el Sector Agropecuario y Agroindustrial, vol. 14, no. 2, pp. 10-17. http://dx.doi.org/10.18684/BSAA(14)10-17.

EVANNO, G., REGNAUT, S. and GOUDET, J., 2005. Detecting the number of clusters of individuals using the software structure: a simulation study. Molecular Ecology, vol. 14, no. 8, pp. 26112620. http://dx.doi.org/10.1111/j.1365-294X.2005.02553.x. PMid:15969739.

GARCÍA AGUILAR, M.A., TERRAZAS, T., SEGURA LEÓN, O., ARIAS, S., VIBRANS, H. and LÓPEZ-MATA, L., 2013. Caracterización molecular de tres especies de Hylocereus (Cactaceae) presentes en México. Revista Fitotecnia Mexicana, vol. 36, no. 1, pp. 13-22. http://dx.doi.org/10.35196/rfm.2013.1.13.

GONZÁLEZ, M.A., PERAZA, A.R. and BROCHERO, H., 2019. Insectos asociados a cultivos de pitaya amarilla (Selenicerus megalanthus) en Inzá, Cauca, Colombia. Revista Colombiana de Entomologia, vol. 45, no. 2, pp. 1-8. http://dx.doi.org/10.25100/socolen.v45i2.7961.

LI, D., ARROYAVE MARTINEZ, M.F., SHAKED, R. and TEL-ZUR, N., 2018. Homozygote depression in gamete-derived dragon-fruit (Hylocereus) lines. Frontiers in Plant Science, vol. 8, no. 2142, pp. 2142. http://dx.doi.org/10.3389/fpls.2017.02142. PMid:29354138.

MARTÍNEZ, M.A., MORILLO, A.C. and REYES-ARDILA, L., 2020. Characterization of the genetic diversity in Passiflora spp. in the Boyacá department, Colombia. Chilean Journal of Agricultural Research, vol. 80, no. 3, pp. 342-351. http://dx.doi.org/10.4067/ S0718-58392020000300342.

MARTÍNEZ, R., LIVERA, M. and MÁRQUEZ, G.J., 2015. Caracterización morfológica y compatibilidad sexual de cinco genotipos de pitahaya (Hylocereus undatus). Agrociencia, vol. 39, no. 2, pp. 183-194.

MEJÍA, H.A., MURIEL, S.B., MONTOYA, C.A. and REYES, C., 2013. In situ morphological characterization of Hylocereus spp. (fam.: Cactaceae) genotypes from Antioquia and Córdoba (Colombia). Revista Facultad Nacional de Agronomía, vol. 66, no. 1, pp. 6845-6854.

MORILLO, A.C., TOVAR, Y.P. and MORILLO, Y., 2016. Caracterización morfológica de Selenicerus megalanthus (K. Schum. ex Vaupel) moran en la provincia de Lengupá. Ciencia y Desarrollo, vol.
7, no. 2, pp. 23-33. http://dx.doi.org/10.19053/01217488. v7.n2.2016.4072.

MORILLO, A.C., TOVAR, Y.P. and MORILLO, Y., 2017. Caracterización molecular de pitahaya amarilla (Selenicereus megalanthus Haw.) en la provincia de Lengupá, Boyacá-Colombia. Biotecnologia en el Sector Agropecuario y Agroindustrial, vol. 15, no. 1, pp. 11-18. http://dx.doi.org/10.18684/BSAA(15)11-18.

NASHIMA, K., HOSAKA, F., SHIMAJIRI, Y., MATSUMURA, M., TARORA, K., URASAKI, N., SHODA, M., NISHITANI, C., SAWAMURA, Y. and YAMAMOTO, T., 2021. SSR marker development and genetic identification of pitaya (Hylocereus spp.) collected in Okinawa, prefecture, Japan. The Horticulture Journal, vol. 90, no. 1, pp. 23-30. http://dx.doi.org/10.2503/hortj.UTD-220.

NEI, M. and LI, W.H., 1979. Mathematical model for studying genetic variation in terms of restriction endonucleases. Proceedings of the National Academy of Sciences of the United States of America, vol. 76, no. 10, pp. 5269-5273. http://dx.doi.org/10.1073/ pnas.76.10.5269. PMid:291943.

OLIVEIRA, M.M., SHUHUA, L., KUMBHA, D.S., ZURGIL, U., RAVEH, E. and TEL-ZUR, N., 2020. Performance of Hylocereus (Cactaceae) species and interspecific hybrids under high-temperatures stress. Plant Physiology and Biochemistry, vol. 153, no. 1, pp. 30-39. http://dx.doi.org/10.1016/j.plaphy.2020.04.044. PMid:32474384.

OTT, J., 1992. Strategies for characterizing highly polymorphic markers in human genes mapping. American Journal of Human Genetics, vol. 51, no. 2, pp. 283-290. PMid:1642229.

PAGLIACCIA, D., VIDALAKIS, G., DOUHAN, G., LOBO, R. and TANIZAKI, G., 2015. Genetic characterization of pitahaya accessions based on amplified fragment length polymorphism analysis. HortScience, vol. 50, no. 3, pp. 332-336. http://dx.doi. org/10.21273/HORTSCI.50.3.332.

PÁSKO, P., GALANTY, A., ZAGRODZKI, P., GYU KU, Y., LUKSIRIKUL, P., WEISZ, M. and GORINSTEIN, S., 2021. Bioactivity and cytoxicity of different species of pitaya fruits-: a comparative study with advanced chemometric analysis. Food Bioscience, vol. 40, no. 1, pp. 1-8.

PRITCHARD, J.K., STEPHENS, M. and DONNELLY, P., 2000. Inference of population structure using multilocus genotype data. Genetics, vol. 155, no. 2, pp. 945-959. http://dx.doi.org/10.1093/ genetics/155.2.945. PMid:10835412.

QUIROZ, B., GARCÍA, M.R., GARCÍA, J. and COLINAS, M.T.B., 2018. Pitaya (Stenocereus spp.): an under-utilized fruit. Journal of the Professional Association for Cactus Development, vol. 20, no. 1, pp. 82-100.

RED DE INFORMACIÓN Y COMUNICACIÓN DEL SECTOR AGROPECUARIO COLOMBIANO - AGRONET, (2021). [viewed August 2021]. Available from: https://www.agronet.gov.co/ estadistica/Paginas/home.aspx/cod=1.

RIFAT, T., KHAN, K. and ISLAM, M.S., 2019. Genetic diversity in dragon fruit (Hylocereus sp.) germplasms revealed by RAPD marker. The Journal of Animal E Plant Sciences, vol. 29, no. 3, pp. 809-818.

THOKCHOM, A., HAZARIKA, B.N. and ANGAMI, T., 2019. Dragon fruit: an advanced potential crop for Northeast India. Agriculture $\mathcal{E}^{\circ}$ Food, vol. 1, no. 1, pp. 253-256.

WRIGHT, S., 1978. Evolution and the genetics of populations, variability within and among natural populations, Chicago: University of Chicago, vol. 4.

ZAIN, N.M., NAZERI, M.A. and AZMAN, N.A., 2019. Assessment on bioactive compounds and the effect of microwave on pitaya peel. Jurnal Teknologi, vol. 81, no. 2, pp. 11-19.

ZHIJIANG, W., FENGZHU, H., LIFANG, H., GUIFENG, L., GUIDONG, L., ZHENYING, L., CHAOAN, L. and HAIYAN, D., 2021. Genetic Characterization of pitaya accessions based on ISSR analysis. Redai Zuowu Xuebao, vol. 42, no. 2, pp. 47-53. 